\title{
A VIOLAÇÃO GENERALIZADA E SISTÊMICA DOS DIREITOS FUNDAMENTAIS NO SISTEMA CARCERÁRIO BRASILEIRO E A ADPF $347^{1}$
}

GENERALIZED AND SYSTEMIC VIOLATION OF FUNDAMENTAL RIGHTS IN THE BRAZILIAN PRISON SYSTEM AND ADPF 347

Letícia Cruz Alves de SOUSA ${ }^{2}$

Marcelo TOFFANO ${ }^{3}$

ISSUE DOI: $10.21207 / 2675-0104.2018 .779$

\section{RESUMO}

$\mathrm{Na}$ óptica do princípio da dignidade humana, que é o axioma principal de todo o ordenamento jurídico e o eixo que orienta os demais direitos e garantias fundamentais de um Estado Democrático de Direito, a presente monografia tem a finalidade de expor o quadro de violação generalizada e sistêmica dos direitos fundamentais durante o cumprimento da pena privativa de liberdade, a configuração do Estado de Coisas Inconstitucional e a importante função da ADPF 347. No que concerne o sistema carcerário brasileiro, há que se apontar que a execução penal humanizada tem dupla destinação: punir de forma adequada o autor do ato ilícito e, principalmente, viabilizar sua reintegração social. Para isto, durante

\footnotetext{
${ }^{1} \mathrm{O}$ presente artigo sintetiza a monografia de conclusão da pesquisa, realizada para o Programa Interno de Bolsas de Iniciação Científica (PIBIC 2017-2018) da Faculdade de Direito de Franca (FDF), Franca/SP.

${ }^{2}$ Discente da Faculdade de Direito de Franca (FDF), Franca/SP. Bolsista do Programa Interno de Bolsas de Iniciação Científica (PIBIC 2017-2018).

${ }^{3}$ Doutor em Direito (Área de Concentração: Função Social no Direito Constitucional) pela Faculdade Autônoma de Direito - FADISP (2014-2018). Mestredo em Direito (Área de Concentração: Direito das Relações Econômico-empresariais) pela Universidade de Franca (2006). Graduado em Direito pela Universidade de Franca (2001). Especialista em Direito Civil pela Universidade de Franca (2003). Atualmente é professor titular da Faculdade de Direito de Franca e orientador de pesquisas científicas. Atua como advogado desde 2002.
} 
a execução da pena, deve o Poder Público assegurar a preservação de todos os direitos não atingidos pela sentença penal condenatória, observando-se as condições mínimas necessárias para a existência digna da pessoa humana. Porém, em contradição à lei brasileira, o regime prisional brasileiro estampa uma realidade inconstitucional de lesão a preceitos fundamentais, em decorrência de atos e omissões dos órgãos públicos, bem como a reiterada incapacidade de mudar tal conjuntura. Em razão disso, pela primeira vez no Brasil, o Supremo Tribunal Federal declara o ECI durante o julgamento da medida cautelar da ADPF 347, exigindo-se desta Corte Constitucional uma postura no sentido do ativismo judicial.

Palavras-chave: Sistema carcerário brasileiro. Direitos fundamentais. Dignidade da pessoa humana. Estado de coisas inconstitucional. ADPF 347.

\begin{abstract}
Based on the principle of dignity of human beings, which is the main axiom of the entire legal system and the axis that guides the fundamental rights and guarantees of a Democratic State of Law, this monograph aims at exposing the framework of generalized and systemic violation of fundamental rights during the execution of the custodial sentence, the configuration of the State of Things Unconstitutional and the important function of the ADPF 347. With regard to the Brazilian prison system, it should be pointed out that humanized criminal enforcement has a dual purpose: to punish the offender in an adequate manner and, mainly, to enable their social reintegration. For this purpose, it is essential that, during the execution of the feather, the public authority ensures the preservation of all rights not reached by the criminal custodial sentence, observing the minimum conditions necessary for existence worthy. However, in contradiction to Brazilian law, the prison system shows an unconstitutional reality of injury to fundamental precepts, as a result of acts and omissions of public agencies, as well as the repeated inability to change such situation. Regarding this unconstitutional framework, for the first time in Brazil, the Supreme Court declares the State of Things Unconstitutional during the trial of the precautionary measure of the ADPF 347, demanding from this Constitutional Court a position in the sense of judicial activism.
\end{abstract}

Keywords: Brazilian prison system. Fundamental rights. Dignity of human beings. State of things unconstitutional. ADPF 347.

INTRODUÇÃO

A presente monografia, com traços de interdisciplinaridade, mas fundamentalmente sob a perspectiva do Direito Constitucional, tem como tema a violação aos direitos fundamentais no sistema carcerário, relativamente ao cumprimento da pena privativa de liberdade, e o desempenho da ADPF 347 frente ao consolidado Estado de Coisas Inconstitucional.

Inicialmente, explorar-se-á amplamente o ordenamento jurídico brasileiro e internacional no que diz respeito aos direitos da população carcerária, principalmente, à luz do princípio da dignidade da pessoa humana. Em um segundo momento, analisar-se-á o quadro fático do sistema carcerário brasileiro com base em dados de órgãos oficiais, como o Infopen, o World Prison Brief, a Organização das Nações Unidas, e outros. Em seguida apresentar-se-á o Estado de Coisas Inconstitucional, destacando-se o seu conceito, e, especialmente, a relação com o quadro 
inconstitucional revelado pelo sistema carcerário brasileiro. Por fim, apurar-se-á a ADPF 347 como instrumento de controle de constitucionalidade, que será analisada desde a propositura pelo Partido Socialismo e Liberdade (PSOL) até o julgamento da medida cautelar pelo STF.

Para tanto, foram realizados estudos respaldados na metodologia analítico-sintética, que tem como objetivo a investigação do todo e de partes, e dogmático-jurídica, traduzida na investigação sistemática do Direito Positivo. A pesquisa se desenvolveu, ainda, a partir de abordagem qualitativa de revisões bibliográficas, como normas constitucionais, infraconstitucionais e internacionais, doutrinas, artigos científicos e jurisprudência.

\section{O ORDENAMENTO JURÍDICO SOBRE OS DIREITOS DA POPULAÇÃO CARCERÁRIA}

A noção de direitos fundamentais está intimamente ligada à de direitos humanos, visto que os primeiros são, em geral, atribuídos à pessoa humana, e, portanto, pertencem à categoria de direitos humanos.

Jorge Miranda sustenta que a expressão "direitos fundamentais" não se resume tão somente ao conjunto de direitos assim declarados pela Constituição Federal, mas abrange também os "direitos resultantes da concepção de Constituição dominante, da idéia de Direito, do sentido jurídico colectivo" ${ }^{4}$.

Percebe-se uma consonância entre a noção de direitos fundamentais apresentadas por Miranda e o que dispõe a própria Constituição Federal de 1988 , em seu art. $5^{\circ}, \S^{\circ}$, que estabelece a existência de um conceito material, para além do conceito formal de direitos fundamentais:

Os direitos e garantias expressas nesta Constituição não excluem outros decorrentes do regime dos princípios por ela adotados, ou dos tratados internacionais em que a República Federativa do Brasil seja parte ${ }^{5}$.

\footnotetext{
${ }^{4}$ MIRANDA, Jorge. Manual de direito constitucional. 3. Ed. Coimbra: Coimbra, 2000, p. 10. t. IV.

${ }^{5}$ BRASIL. Constituição (1988). Constituição da República Federativa do Brasil. Brasília, DF, Senado, 1988.
} 
Neste sentido, mesmo que alguns direitos não constem expressamente do rol originariamente definido, pelo Constituinte, como direitos fundamentais, por seu conteúdo e relevância podem assim ser equiparados. É possível, pois, que normas do Direito Internacional e infraconstitucionais sejam equiparadas às da própria Constituição, desde que haja harmonização com a ordem de valores constitucionais.

Fato é que, no Estado Democrático de Direito, pressupõe-se a garantia da inviolabilidade dos direitos fundamentais, nos sentidos formal e material, exigindo-se forçosamente o controle efetivo dos abusos cometidos pelo Poder Público, de forma a obstar possíveis supressões destes direitos, seja no âmbito individual, seja no coletivo.

O Direito Internacional preocupa-se com a uniformização dos diversos ordenamentos internos heterogêneos, com o intuito de pacificar as relações entre Estados. Daí a importância dos Tratados Internacionais e a obrigatoriedade do cumprimento das determinações impostas aos Estados que expressamente anuírem com a sua adoção, não se deixando de observar o livre e pleno exercício da soberania.

Predomina no Direito Internacional Público o princípio $d a$ prevalência dos direitos humanos, de forma que cada Estado deve respeitar os direitos humanos em suas relações externas.

A partir do pós-guerra, em resposta aos abusos e atrocidades cometidos durante o período nazista, observa-se um progressivo movimento de internacionalização dos direitos humanos, representando o repúdio da comunidade internacional à concepção positivista de um ordenamento jurídico alheio a princípios éticos.

Começa, pois, a ser delineado o sistema normativo internacional de proteção e defesa dos direitos humanos e limitação do poder estatal, sucedendo-se através da solidificação de um aparato global de tutela de direitos, aos quais o princípio da dignidade humana constitui o referencial ético.

Adotada pela Organização das Nações Unidas, em 10 de dezembro de 1948, a Declaração Universal dos Direitos Humanos propõe a especificação dos direitos comuns a todos os homens, refletindo os parâmetros protetivos mínimos para a custódia da dignidade humana, bem como a consagração de valores básicos universais.

Logo em seu preâmbulo declara a dignidade um axioma próprio da pessoa humana, que é titular de direitos iguais e inalienáveis, visto que é requisito único e exclusivo a condição de ser humano. 
Estabelece em seu artigo III que "todo indivíduo tem direito à vida, à liberdade e à segurança pessoal", no sentido de que ninguém poderá ser privado de sua vida, tal como ver reduzidas a sua liberdade e a sua segurança.

Já em seu artigo V, trazendo para a esfera da execução da pena, percebe-se o esforço para banir a tortura e as penas cruéis, de forma a extinguir a cultura da violência que existe na relação entre os agentes do Estado e os apenados, observando que "ninguém será submetido à tortura nem a tratamento ou castigo cruel, desumano ou degradante".

A Convenção contra a Tortura e outros Tratamentos ou Penas Cruéis, Desumanos e Degradantes, adotada pela ONU em 28 de setembro de 1984, ensejando a maior eficácia dessa luta e reconhecendo direitos inerentes à dignidade da pessoa humana, dispôs sobre a tortura, considerando-a crime que ofende o Direito Internacional. Aliás, propõe, em consonância com a humanização das penas criminais, o comprometimento de cada Estado-parte de coibir os atos que constituam tratamentos ou penas cruéis, desumanos ou degradantes que não constituam propriamente a tortura definida anteriormente.

Sob a mesma perspectiva da dignidade da pessoa humana, a Convenção Americana de Direitos Humanos, conhecida também como Pacto de São José da Costa Rica, foi assinada em 22 de novembro de 1969, e ratificada pelo Brasil em 06 de novembro de 1992. Versa, basicamente, sobre os direitos de primeira dimensão - aqueles delineados como direitos do indivíduo frente ao Estado -, como se percebe em ser art. $5^{\circ}$, que dispõe a respeito do direito à integridade física, psíquica e moral, repudiando a tortura e tratamentos degradantes e cruéis. Tal dispositivo ainda contempla a individualização da pena, além da separação dos condenados e da finalidade social da pena.

Ante o exposto, firma-se o entendimento da primazia do princípio da dignidade humana, sendo o paradigma do Direito Internacional dos Direitos Humanos. Tal princípio se revelará também eixo de orientação do estudo da Constituição Federal e da Lei de Execução Penal; e, eventualmente, de todo o constitucionalismo contemporâneo.

A Constituição Federal de 1988, de forma utópica, reestabeleceu a inviolabilidade de direitos e liberdades básicas, além de instituir regras progressistas. Utópica porque, apesar da amplitude de garantias individuais constantes do seu texto, percebe-se o desacordo com a realidade brasileira, visto que muitos preceitos não são postos em prática ou, quando o são, é feito de forma desigual. 
Inicialmente, cumpre consignar o incontestável eixo ético que abarca os direitos fundamentais, enquanto, de acordo com George Marmelstein, "valores básicos para uma vida digna em sociedade”, já que "estão intimamente ligados à ideia de dignidade da pessoa humana e de limitação do poder"'.

No tocante à pena privativa de liberdade, a dignidade da pessoa humana percorre todo o aparato constitucional e reflete de modo profundo no direito penal, atuando como limitador do poder punitivo do Estado, além de consagrar a humanização da pena.

A dignidade da pessoa humana, como bem define Ingo Wolfgang Sarlet, é:

[...] a qualidade intrínseca e distintiva de cada ser humano que o faz merecedor do mesmo respeito e consideração por parte do Estado e da comunidade, implicando, neste sentido, um complexo de direitos e deveres fundamentais que assegurem a pessoa tanto contra todo e qualquer ato de cunho degradante e desumano, como venham a lhe garantir as condições existenciais mínimas para uma vida saudável, além de propiciar e promover sua participação ativa co-responsável nos destinos da própria existência e da vida em comunhão dos demais seres humanos ${ }^{7}$.

Para tanto, impõe-se ao Estado uma série de condutas positivas e deveres de abstenção, com o intuito de acatar, preservar e viabilizar de fato a dignidade da pessoa humana.

O texto contido no "caput" do art. $5^{\circ}$, da carta constitucional, muito se assemelha com as demais declarações internacionais de direito, como se vê:

Art. $5^{\circ}$. Todos são iguais perante a lei, sem distinção de qualquer natureza, garantindo-se aos brasileiros e aos estrangeiros residentes no País a inviolabilidade do direito à vida, à igualdade, à segurança, e à propriedade $[\ldots]^{8}$.

Estabelece-se, logo, o dever ético-jurídico comum a todos os seres humanos, de respeito e tolerância ao outro, independentemente de qualquer condição e especificidade.

\footnotetext{
${ }^{6}$ MARMELSTEIN, George. Curso de direitos fundamentais. 6. ed. São Paulo: Atlas, 2016, p. 1617.

${ }^{7}$ SARLET, Ingo Wolfgang. A eficácia dos direitos fundamentais. 2. ed. Porto Alegre: Livraria do Advogado, 2001, p. 322-323.

${ }^{8}$ BRASIL. Constituição (1988). Constituição da República Federativa do Brasil. Brasília, DF, Senado, 1988.
} 
O rol do art. 50, do Título "Dos Direitos e Garantias Fundamentais" da Constituição Federal, prevê: o direito à vida, abrangendo a noção de qualidade mínima existencial; o direito à integridade física e psíquica, e, como reflexo, a proibição da tortura e de todo e qualquer tratamento desumano e degradante e a proibição de penas cruéis; a separação dos presos de acordo com natureza do delito, a idade e o sexo do apenado; as condições para que mães presidiárias possam permanecer com seus filhos durante o período de amamentação; o direito à devida indenização por erro judiciário.

Por fim, a constituição cidadã, como é popularmente titulada no campo jurídico, dispõe sobre a tutela internacional dos Direitos Humanos. De acordo com o já aludido $\S 2^{\circ}$, do art. $5^{\circ}$, "os direitos e garantias expressos nesta constituição não excluem outros decorrentes do regime e dos princípios por ela adotados, ou dos tratados internacionais em que a República Federativa do Brasil seja parte".

Pois bem, nota-se a estreita conexão entre a Constituição Federal e os Tratados Internacionais, como se já pôde verificar anteriormente. Portanto, mesmo que alguns direitos estabelecidos em Tratado ou Convenção Internacional não integrem o capítulo dos "Direitos e Deveres Individuais e Coletivos", estarão assim vinculados desde que o País seja signatário.

Encerrando-se o ordenamento jurídico acerca dos direitos dos condenados a pena privativa de liberdade, há que se falar da Lei n. 7.210, de 11 de julho de 1984, que instituiu no Brasil a Lei de Execução Penal, trazendo em seu bojo a harmonização entre o interesse da sociedade de ver o ato ilícito punido, através da efetivação da sentença ou decisão criminal, e a preservação dos direitos e garantias daquele que o cometeu, assegurando-lhe condições eficazes para a adequada integração social.

Criada há mais de 30 anos, antecedendo, até mesmo, a atual Constituição Federal, a LEP expressa o anseio da comunidade jurídica nacional da época de se consolidar uma execução penal jurisdicionalizada sob o enfoque da humanização da pena, diante do cenário político de decadente ditadura militar em que o Brasil estava inserido. O processo de jurisdicionalização pressupõe a eficácia do princípio da legalidade e a consecutiva defesa dos direitos fundamentais dos condenados, aos quais é dever do Estado prestar a tutela jurisdicional.

Em obediência ao princípio da legalidade, o art. $3^{\circ}$, da Lei de Execução Penal, dispõe que "ao condenado e ao internado serão assegurados todos os direitos não atingidos pela sentença ou pela lei”, ou 
seja, todos os direitos não atingidos pela condenação deverão ser conservados, já que só a lei pode criar a pena (nulla poena sine lege). Cumpre, pois, ao sistema penitenciário assegurar a incolumidade de todos os direitos fundamentais dos presos, não podendo ser imposta nenhuma restrição além daquela atingida pela pena.

Visto que este tipo de pena se limita a restringir tão somente a liberdade do indivíduo, não pode, de forma alguma, atingir a dignidade inerente à pessoa humana, bem como os demais direitos e liberdades individuais, que condicionam a legitimidade da atuação do Poder Público em um Estado Democrático de Direito. Portanto, compete à LEP a efetivação da execução penal com garantia das condições mínimas existencial para uma vida digna enquanto no cumprimento da pena privativa de liberdade, além de propiciar a satisfatória ressocialização do apenado.

\section{O QUADRO DO SISTEMA CARCERÁRIO BRASILEIRO}

Como é cediço, o sistema carcerário brasileiro há muito se encontra em situação alarmante, revelando de forma progressiva um contexto caótico e incoerente de lesão a preceitos fundamentais decorrente da negligência e da incapacidade dos poderes públicos.

Percebe-se, no cenário mencionado, que o direito de punir monopolizado pelo Estado tem priorizado penalizar gravemente o sujeito pelo ato criminoso cometido em detrimento da reintegração social tanto idealizada pelo ordenamento jurídico brasileiro. A execução penal, entretanto, preza pela humanização da pena, consubstanciando-se na garantia da preservação da integridade física e moral em conformidade com o princípio constitucional da dignidade humana.

No plano ideal, o sistema penitenciário deveria atuar de forma a proporcionar a plena fruição de todos os direitos não atingidos pela sentença, respeitando-se, pois, os direitos fundamentais do condenado. Lamentavelmente, não é o que se verifica.

O Brasil representa, hoje, a terceira maior população prisional do mundo, enquanto a taxa de ocupação média é de $197,4 \%$ em todo o território brasileiro, o que representa quase o dobro de presos por vagas ${ }^{9}$.

\footnotetext{
${ }^{9}$ INFOPEN - Ministério Da Justiça - Levantamento nacional de informações penitenciárias dados consolidados Junho/2016. Disponível em: <http://depen.gov.br/DEPEN/noticias-
} 
Essa superlotação, além de desrespeitar o parâmetro fixado pela resolução n. ${ }^{\circ} 05$ de 25 de novembro de 2016, do Conselho Nacional de Política Criminal e Penitenciária - que fixa o parâmetro de 137,5\% como percentual máximo de detentos sobressalentes nas prisões -, ainda fere, de forma direta, o princípio da dignidade da pessoa humana, acaba por causar ou, ao menos, agravar outros problemas do sistema carcerário brasileiro e cria óbice à ressocialização do condenado.

A Lei de Execução Penal estabelece que os condenados à pena privativa de liberdade devem ter acesso integral à saúde, compreendendo atendimento médico, farmacêutico e odontológico garantido pelo Estado. Tal proteção guarda vínculo íntimo com a proteção de todos os outros direitos previstos na Constituição Federal, desde que não atingidos pela sentença ou pela lei.

No levantamento de junho de 2016, o Infopen analisou a existência de estrutura para o cuidado básico com a saúde, inferindo, então, que $85 \%$ da população carcerária brasileira encontravam-se custodiada em unidades prisionais em conformidade com a estrutura estabelecida para a assistência à saúde. Isso quer dizer que $15 \%$ das pessoas privadas de liberdade encontram-se em unidades sem módulo de saúde, concluindo-se que o Estado brasileiro ainda não consegue assegurar a o acesso universal à assistência à saúde.

A LEP prevê que as celas apresentem condições de salubridade "pela concorrência dos fatores de aeração, insolação e condicionamento térmico adequado à existência humana", conforme art. 88, parágrafo único, alínea "a". Todavia, em vista da superlotação, estas áreas se tornam insalubres, desrespeitando tal disposição.

As condições de insalubridade às quais as pessoas privadas de liberdade são submetidas é distúrbio comum a todas as prisões brasileiras, que fere não só a Lei de Execução Penal no que diz respeito à salubridade do ambiente como requisito básico da unidade celular, mas, também, viola a existência digna implícita nos direitos constitucionais à integridade física e psíquica e à vida.

Concorrem para a situação de calamidade na saúde carcerária, também, a alimentação insatisfatória e as más condições das instalações sanitárias. A respeito da alimentação, constituem obstáculos à efetividade desta a corrupção e distribuição desigual da comida entre os presídios, bem como a baixa qualidade da comida servida. Já em se tratando das condições

1/noticias/infopen-levantamento-nacional-de-informacoes-penitenciarias2016/relatorio 2016 22111.pdf>. Acesso em: 08 jul. 2018. 
de higiene, percebe-se, ainda hoje, que estão em desacordo com os padrões estabelecidos em Regras Mínimas para o Tratamento dos Presos no Brasil.

No mais, compreendendo que a transmissão de doenças é um dos principais fatores determinantes para a tão elevada taxa de mortalidade entre a população carcerária, a recente Resolução do Conselho Nacional de Política Criminal e Penitenciária - CNPCP n. ${ }^{\circ}$ 3, de 7 de junho de 2018, estabelece recomendações no sentido de fazer cessar a transmissão de doenças como HIV, hepatites virais e tuberculose dentro do sistema prisional.

Além da ampliação e qualificação dos serviços de saúde física, há que se atentar, também, com a saúde mental dos presos, promovendo, por conseguinte, ações de prevenção dos agravos psicossociais resultantes do encarceramento, bem como cuidando das situações de alteração do estado psíquico decorrente do uso de álcool e drogas.

A violência interna e os abusos cometidos por agentes penitenciários, como a prática da tortura e maus-tratos, também são oriundos de incapacidades da Administração, que perpetuam a lesividade à integridade física e moral dos apenados, integralmente incompatível com o princípio da dignidade humana.

Conforme visto, o Direito Internacional dos Direitos Humanos repudia a prática de tortura e maus-tratos, uma vez que é totalmente incompatível com o princípio da dignidade humana. No âmbito execução penal tais práticas contaminam, ainda, a humanização da pena e a finalidade de ressocialização do condenado.

O Direito Brasileiro, ao instituir a Lei n. ${ }^{\circ}$ 9.455/97, definiu a prática de tortura como crime inafiançável e insuscetível de graça ou anistia, além de impor sanções ao agente ativo. Determinou, ademais, circunstância qualificadora a hipótese de resultar lesão corporal de natureza grave ou gravíssima; e causa de aumento quando o crime for cometido agente público, acarretando a perda do cargo, função ou emprego público e a interdição para o seu exercício pelo dobro do prazo da pena aplicada. No entanto, ainda há um longo caminho a ser percorrido para a abolição dessas práticas por policiais e agentes penitenciários contra os condenados a pena privativa de liberdade, já que a impunidade constitui uma disfunção crônica que estimula os abusos subsequentes.

O Levantamento Nacional de Informações Penitenciárias Infopen demonstrou que em junho de 2016, a taxa total de óbitos da população prisional referente ao primeiro semestre daquele ano é de 13,6 para cada grupo de 10 mil pessoas privadas de liberdade. Os números 
apresentados pelo Infopen ainda deixam claro uma realidade embaraçosa, qual seja: a incapacidade do Estado de proteger a vida das pessoas privadas de liberdade, acusando um Sistema Prisional Brasileiro violento, omisso e ineficiente.

Por fim, encerrando-se os dados do quadro fático, há que se apontar a ineficiência dos programas de educação e trabalho, que, mesmo possibilitando a remição da pena, ainda representam uma baixa taxa de adesão nas prisões brasileiras: segundo os dados do Infopen, em junho de 2016, apenas 12\% dos presos desenvolviam alguma das atividades educacionais previstas na Lei de Execução Penal, e, 15\%, atividade laboral, interna ou externa. Vale ressaltar que ambas as atividades mencionadas apresentam finalidade educativa e produtiva, constituindo, pois, dever social e condição de dignidade humana, tão importante para a reintegração do apenado à sociedade.

\section{$4 \quad$ O ESTADO DE COISAS INCONSTITUCIONAL}

O cenário político-institucional a que se remete a origem do Estado de Coisas Inconstitucional ostenta o episódio de ativismo judicial da América Latina, entre o final dos anos 80 e início dos 90, cujo paradigma é a Corte Constitucional colombiana. Este momento foi marcado pela ocorrência de grandes mudanças constitucionais voltadas à consolidação da democracia e difusão de direitos fundamentais e sociais, como se pode atestar da Constituição Federal brasileira de 1988.

Sob influência direta da ideia de structural remedies, o Estado de Coisas Inconstitucional foi declarado, de forma pioneira, justamente pela Corte Constitucional colombiana, na Sentencia de Unificación (SU) n. ${ }^{\circ}$ 559, de 1997, que tratava dos direitos previdenciários de saúde de professores municipais.

No caso citado, restou documentada a situação de 45 professores dos municípios de María La Baja e Zambrano, que, apesar de contribuírem devidamente com 5\% de seus subsídios para o Fundo de Prestación Social, não recebiam a cobertura de saúde ou de seguridade correspondente à contribuição. As autoridades locais, ao recusar os direitos previdenciários, invocaram a escassez de recursos orçamentários.

É nesta conjuntura que entra a Corte, que, reconhecendo que os 45 educadores não gozavam dos direitos subjetivos que tinham titularidade, incumbiu-se, ainda, de investigar a falha estatal precedente à 
violação massiva dos direitos fundamentais em questão. Chegou-se, logo, à conclusão de que o descumprimento da obrigação previdenciária não ocorrera tão-somente neste caso, mas mostrava-se generalizado, além de que "a falha não poderia ser atribuída a um único órgão, e sim que essa seria estrutural ${ }^{10}$ ", conforme consigna Carlos Alexandre de Azevedo Campos.

A Corte Constitucional da Colômbia, diante da constatada complexidade da "situação estrutural que lesa, de maneira permanente, o exercício dos direitos fundamentais de um número amplo, indeterminado, de pessoas que não instauraram a demanda ${ }^{11}$ ", decidiu pela declaração do Estado de Coisas Inconstitucional, determinando prazo razoável para que os municípios corrigissem tal inconstitucionalidade.

Há que se consignar que a atuação do ECI se dá no âmbito dos direitos sociais e econômicos, que, no entanto, não são efetivados. Depreende-se, portanto, que o objeto principal do ECI circunscreve os direitos sociais e econômicos e as políticas públicas.

Visando o alcance de um conceito apto e objetivo do Estado de Coisas Inconstitucional, Campos anuncia que, primeiramente, deve-se fazer um levantamento dos pressupostos, quais sejam: (I) a constatação de um quadro de violação massiva e contínua de uma variedade de direitos fundamentais, atingindo um número amplo e indeterminado de pessoas; (II) a falha estrutural caracterizada pela ausência ou deficiência das políticas públicas do Estado, que, na posição de garante, se mostra omisso de forma reiterada e persistente em relação à defesa e promoção dos direitos fundamentais; (III) a atribuição da responsabilidade não a um só órgão, mas a uma pluralidade deles; $(I V)$ a possibilidade de um alto número de lesados buscarem a proteção e a reparação judicial em relação aos direitos violados, capaz de gerar congestionamento da máquina judiciária.

O Estado de Coisas Inconstitucional não significa, portanto, uma ação judicial, mas ferramenta processual por meio da qual cortes e juízes constitucionais declaram uma conjuntura inconstitucional, caracterizada pela violação generalizada e sistêmica dos direitos fundamentais de um conjunto de sujeitos, em decorrência de falha estrutural do Estado, cuja

\footnotetext{
${ }^{10}$ CAMPOS, Carlos Alexandre de Azevedo. Estado de coisas inconstitucional. Salvador: JusPodivm, 2016, p. 121.

11 HERNÁNDEZ, Clara Inés Vargas. La Garatía de la dimensión objetiva de los derechos fundamentales y labor del juez constitucional colombiano em sede de acción de tutela: el llamado "estado de cosas inconstitucional". Revista del Centro de Estudios Constitucionales Ano 1, $\mathrm{n}^{\circ} 1$, Universidad de Talca, Chile, 2003, p. 214.
} 
superação está sujeita à responsabilidade e esforços de uma pluralidade de órgãos públicos.

Para além dos efeitos diretos imediatos, que afetam tão-somente os litigantes, a quem se destina a ordem e quem se beneficia com ela, há que se atentar para as transformações sociais. Percebe-se, nos casos em que foi declarado o ECI, uma confluência entre a atuação judicial ativista e a cooperação da sociedade, em busca da superação do contexto contrário à Constituição e aos Direitos Humanos, de tamanha valia em favor do Estado Democrático de Direito.

Relacionando o ECI ao sistema carcerário brasileiro, percebe-se que a principal preocupação não é com o estabelecimento de direitos dos quais os presos são destinatários, mas com a efetividade de tais direitos já existentes, dando ênfase à dignidade da pessoa humana. No que diz respeito ao cumprimento da pena privativa de liberdade, é no âmbito da conformidade entre o ordenamento jurídico e a realidade que se depara com a falha estrutural do Estado.

Com relação à existência de condição de violação massiva e generalizada de direitos fundamentais, há que se pontuar inequívoco o preenchimento de tal pressuposto, já que, ao longo deste artigo, em várias oportunidades ficou demonstrado a desconformidade da situação carcerária com o texto constitucional e demais direitos humanos a ele harmonizados. Faz-se mister, mais uma vez, dar ênfase ao desrespeito à dignidade da pessoa humana, que tem tornado tal princípio letra morta em se tratando de cumprimento de pena privativa de liberdade.

Quanto à omissão reiterada e persistente do Estado, pode-se destacar o funcionamento deficiente do aparato estatal como um todo, que sucede a violação aos direitos, e a incapacidade de se reverter esta conjuntura inconstitucional. A falha estrutural ocorre, principalmente, na esfera de competência do Executivo e do Legislativo, que, legitimados a criar e aprovar políticas públicas, permanecem inertes ou o fazem de maneira ineficaz para a proteção dos direitos dos presos.

O terceiro pressuposto preenchido pelo sistema carcerário brasileiro diz respeito à necessidade da atuação do conjunto de órgãos, abrangendo os três Poderes e os diversos níveis federativos, para alcançar a superação do quadro inconstitucional. Este pressuposto está diretamente ligado ao anterior. Se a violação generalizada e sistêmica dos direitos fundamentais decorre de uma falha estrutural, tão-somente o conjunto de contribuições de diversos órgãos e entidades, direcionados pelo ativismo judicial, poderá revertê-la. 
A configuração do quarto e último pressuposto - a potencialidade de um grande número de lesados virem a recorrer às vias judiciárias decorre do fato de a situação carcerária brasileira dar margem a desmedidas demandas, especialmente, indenizatórias por danos morais. É notório, pois, que tal situação pode resultar no congestionamento da máquina judiciária.

Presentes os quatro pressupostos, ao declarar o Estado de Coisas Inconstitucional, espera-se do Supremo Tribunal Federal, enquanto Corte Constitucional, que incorpore à sua atuação o ativismo judicial, permitindo, desta forma, que interfira sobre a elaboração, implementação e acompanhamento de políticas públicas. Esta atuação, no âmbito do sistema carcerário brasileiro, deve voltar-se aos seguintes objetivos: diminuição do aumento contínuo da população carcerária, redução do déficit de vagas nas prisões e melhoria das condições às quais os presos são submetidos durante o cumprimento da pena privativa de liberdade ou da prisão cautelar.

Conforme se revelará a seguir, a arguição de descumprimento de preceito fundamental, estabelecida pela Constituição Federal de 1988 é o principal instrumento de controle de constitucionalidade para a declaração do ECI, visto que abrange as noções de falha estrutural e de realidade inconstitucional.

\section{A ARGUIÇÃO DE DESCUMPRIMENTO DE PRECEITO FUNDAMENTAL №. 347}

Conforme determina o art. $102, \S 1^{\circ}$, da Constituição Federal, "a argüição de descumprimento de preceito fundamental, decorrente desta Constituição, será apreciada pelo Supremo Tribunal Federal, na forma da lei". Depreende-se da última parte do dispositivo em questão, pois, que a ADPF tem eficácia limitada, dependendo de regulamentação por lei, que é o que fez a Lei n. ${ }^{\circ}$ 9.882/99.

Arguição de descumprimento de preceito fundamental é a medida de natureza judicial que suscita o controle concentrado de constitucionalidade voltado aos atos do Poder Público que violam manifestamente esta Constituição. Revela, contudo, "quão largo é seu espectro de incidência, pois lida com conceitos bastante amplos, tais como 'preceito fundamental' e 'atos do poder público', que também já indicam 
sua singularidade diante de outros mecanismos de controle da constitucionalidade ${ }^{12}$ ".

Para compreender seu alcance de tal medida, é necessário, primeiramente, consignar preceito fundamental e atos do poder público. A primeira expressão abrange os direitos e garantias fundamentais estabelecidos na Constituição Federal, além dos princípios e objetivos fundamentais deste Estado Democrático de Direito. Enquanto a segunda inclui as condutas comissivas e omissivas, lícitas ou ilícitas, dos Poderes Executivo, Legislativo e Judiciário. O parágrafo único, do art. $1^{\circ}$, da Lei n. ${ }^{\circ}$ 9.882/99, dispõe, ainda, a extensão ao "relevante fundamento da controvérsia constitucional sobre lei ou ato normativo federal, estadual ou municipal, incluídos os anteriores à Constituição".

O Partido Socialismo e Liberdade (PSOL), partido político com representação no Congresso Nacional, ajuizou, em maio de 2015, perante o Supremo Tribunal Federal, Arguição de Descumprimento de Preceito Fundamental (ADPF 347), cujo principal objetivo era o reconhecimento do Estado de Coisas Inconstitucional do sistema penitenciário brasileiro, e, em função disto, fosse adotada uma série de medidas voltadas à reparação das graves lesões aos preceitos fundamentais, decorrentes de atos positivos e negativos dos Poderes Públicos da União, dos Estados e do Distrito Federal.

Consignou-se que, apesar de, em regra, não cumprir ao Poder Judiciário a implementação de políticas públicas, diante da falha estrutural consequente da incapacidade demonstrada pela Administração, resultando lesão a preceitos fundamentais, fez-se mister a intervenção judicial. Acrescentando-se que o conjunto dos pedidos formulados no final da petição inicial mostra-se essencial para a efetiva garantia dos direitos fundamentais e afastamento do Estado de Coisas Inconstitucional verificado no sistema penitenciário brasileiro.

Em momento oportuno da peça inicial, retirou do Estado a legitimidade de invocar o princípio da reserva do possível para limitar a denegação dos direitos e garantias fundamentais do preso, posto que se enquadram na concepção do mínimo existencial. Isto porque, o Estado, na posição de garante, assume a responsabilidade civil objetiva em relação aos danos verificados na prisão.

Apresentou, por fim, um rol de medidas que o Supremo Tribunal Federal deve impor aos Poderes Públicos com o fito de superar o Estado

${ }^{12}$ VARGAS, Alexis Galiás de Souza; BASTOS, Celso Ribeiro. Argüição de descumprimento de preceito fundamental. São Paulo: Revista dos Tribunais, 2000, p. 69. 
de Coisas Inconstitucional firmado no sistema carcerário brasileiro, quais sejam: a) elaboração e implementação de planos pela União e Estados, sob monitoramento judicial; $b$ ) declarar a aplicabilidade imediata da audiência de custódia; c) consideração do estado de coisas inconstitucional ao se decidir sobre a prisão provisória, e; $d$ ) consideração do estado de coisas inconstitucional quando da aplicação e execução da pena.

Em sede de medida cautelar, com fundamento no art. $5^{\circ}$, da Lei n. 9 $^{\circ} 882 / 99$, o Requerente interpôs os seguintes pedidos em face da urgência e da verossimilhança das alegações:

a) Determine a todos os juízes e tribunais que, em cada caso de decretação ou manutenção de prisão provisória, motivem expressamente as razões que impossibilitam a aplicação das medidas cautelares alternativas à privação de liberdade, previstas no art. 319 do Código de Processo Penal.

b) Reconheça a aplicabilidade imediata dos arts. 9.3 do Pacto dos Direitos Civis e Políticos e 7.5 da Convenção Interamericana de Direitos Humanos, determinando a todos os juízes e tribunais que passem a realizar audiências de custódia, no prazo máximo de 90 dias, de modo a viabilizar o comparecimento do preso perante a autoridade judiciária em até 24 horas contadas do momento da prisão.

c) Determine aos juízes e tribunais brasileiros que passem a considerar fundamentadamente o dramático quadro fático do sistema penitenciário brasileiro no momento de concessão de cautelares penais, na aplicação da pena e durante o processo de execução penal.

d) Reconheça que como a pena é sistematicamente cumprida em condições muito mais severas do que as admitidas pela ordem jurídica, a preservação, na medida do possível, da proporcionalidade e humanidade da sanção impõe que os juízes brasileiros apliquem, sempre que for viável, penas alternativas à prisão.

e) Afirme que o juízo da execução penal tem o poder-dever de abrandar os requisitos temporais para a fruição de benefícios e direitos do preso, como a progressão de regime, o livramento condicional e a suspensão condicional da pena, quando se evidenciar que as condições de efetivo cumprimento da pena são significativamente mais severas do que as previstas na ordem jurídica e impostas pela sentença condenatória, visando assim a preservar, na medida do possível, a proporcionalidade e humanidade da sanção.

f) Reconheça que o juízo da execução penal tem o poder-dever de abater tempo de prisão da pena a ser cumprida, quando se evidenciar que as condições de efetivo cumprimento da pena foram significativamente mais severas do que as previstas na ordem jurídica e impostas pela sentença condenatória, de forma a preservar, na medida do possível, a proporcionalidade e humanidade da sanção. 


\begin{abstract}
g) Determine ao Conselho Nacional de Justiça que coordene um ou mais mutirões carcerários, de modo a viabilizar a pronta revisão de todos os processos de execução penal em curso no país que envolvam a aplicação de pena privativa de liberdade, visando a adequá-los às medidas "e" e "f" acima.

h) Imponha o imediato descontingenciamento das verbas existentes no Fundo Penitenciário Nacional - FUNPEN, e vede à União Federal a realização de novos contingenciamentos, até que se reconheça a superação do estado de coisas inconstitucional do sistema prisional brasileiro. ${ }^{13}$
\end{abstract}

Já em caráter definitivo, o rol dos pedidos é mais extenso, abrangendo desde a declaração do Estado de Coisas Inconstitucional do sistema penitenciário brasileiro e a confirmação das medidas cautelares aludidas, até os passos a serem seguidos durante até a implementação de um Plano Nacional voltado à superação deste ECI, que são: $1^{o}$ ) elaboração pelo Governo Federal; $2^{\circ}$ ) a submissão à analise do Conselho Nacional de Justiça, da Procuradoria Geral da República, da Defensoria Geral da União, do Conselho Federal da Ordem dos Advogados do Brasil, do Conselho Nacional do Ministério Público, além da sociedade civil; $3^{\circ}$ ) deliberação e possível homologação pelo STF; $4^{\circ}$ ) elaboração de plano estadual ou distrital em conformidade com o Plano Nacional; $5^{\circ}$ ) submissão para análise dos mesmos órgãos e instituições que se manifestaram sobre o Plano Nacional; $\sigma^{\circ}$ ) deliberação sobre cada plano estadual e distrital, e, por último; $7^{\circ}$ ) monitoração da implementação do Plano Nacional e dos planos estaduais e distritais.

Nota-se, com relação aos pedidos formulados pelo Requerente, a construção de ampla responsabilidade estatal, congregando todos os Poderes, no mesmo sentido que tem entendido as instâncias internacionais de defesa dos direitos humanos. Mas, ao menos em requerimento cautelar, ao Poder Judiciário é dado ênfase, indicando a sua importante função diante de toda a situação prisional no Brasil, que guarda relação com a qualidade das decisões judiciais, principalmente no tocante a fundamentação.

Em setembro de 2015, foi posta a julgamento em plenário a medida cautelar da ADPF 347, tendo como relator o Ministro Marco Aurélio. Apesar do caráter definitivo do pedido de reconhecimento do Estado de Coisas Inconstitucional, a maioria dos Ministros do STF não se absteve de declará-lo e comentar o tema. Neste sentido, manifestou-se o Ministro Edson Fachin:

13 BRASIL. Supremo Tribunal Federal. Ação de Arguição de Descumprimento de Preceito Fundamental n. ${ }^{\circ} 347$. Rio de Janeiro, 26 de maio de 2015. 


\begin{abstract}
Quando o Estado atrai para si a persecução penal e, por conseguinte, a aplicação da pena visando à ressocialização do condenado, atrai, conjuntamente, a responsabilidade de efetivamente resguardar a plenitude da dignidade daquele condenado sob sua tutela. A pena não pode se revelar como gravame a extirpar a condição humana daquele que a cumpre. Deve funcionar sim como fator de reinserção do transgressor da ordem jurídica, para que reassuma seu papel de cidadão integrado à sociedade que lhe cerca. [...] Creio que, dessa forma, o Supremo Tribunal Federal está, em cognição sumária, reconhecendo a impossibilidade de que se mantenha o atual estado de coisas inconstitucional do sistema carcerário; reconhecendo a importância da proteção internacional dos direitos humanos; dando indicações ao Poder competente para que tome medidas, desde logo, aptas a dar início a um processo de mudança da atual situação de violação massiva de direitos fundamentais dos encarcerados e deixando para analisar mais detidamente o caso e os demais pedidos requeridos quando da devida análise do mérito ${ }^{14}$.
\end{abstract}

Após relatório e discussão acerca dos pedidos de medida cautelar formulados na inicial, ficou acordado pelos Ministros do Supremo Tribunal Federal, por maioria, o deferimento daqueles relacionados às alíneas " $b$ " correspondente à implementação das audiências de custódia - e "h" relacionada à liberação do saldo acumulado do Fundo Penitenciário Nacional (Funpen).

Sobre a implementação da audiência de custódia, ficou reconhecido, pois, a aplicabilidade imediata dos arts. 9.3 do Pacto Internacional dos Direitos Civis e Políticos e 7.5 da Convenção Interamericana dos Direitos Humanos. De tal forma, determinou-se, pois, a todos os juízes e tribunais que realizem a audiência de custódia, observando-se o prazo máximo de noventa dias para a instauração, de modo a possibilitar ao preso o comparecimento perante a autoridade judiciária em até 24 horas, a se contar do momento da prisão. O Ministro Luís Roberto Barroso afirmou, ainda, ao deferir a cautelar em questão, que "o prazo de vinte quatro horas que se pede na cautelar pode ser extraído do art. 306, $\S 1^{\circ}$, do Código de Processo Penal".

A respeito do saldo acumulado do Funpen, foi determinado à União sua liberação para a utilização de acordo com o fim para o qual foi criado, além da vedação da realização de novos contingenciamentos. A esse respeito, o Ministro Relator apontou, em voto, que "os valores não utilizados deixam de custear não somente reformas dos presídios ou a

14 BRASIL. Supremo Tribunal Federal. Ação de Arguição de Descumprimento de Preceito Fundamental n. ${ }^{\circ}$ 347. Rio de Janeiro, 26 de maio de 2015. 
construção de novos, mas também projetos de ressocialização que, inclusive, poderiam reduzir o tempo no cárcere".

As demais medidas cautelares - contidas em alíneas "a", "c", "d", "e" e "f", e já apresentadas em momento oportuno - foram indeferidas pelo fato de não terem alcançado a maioria absoluta de votos dos membros do plenário do STF. Mas, concordou a maioria dos Ministros do STF, que tais itens já compõem o ordenamento jurídico brasileiro, além de possuírem meios próprios de correção.

Por fim, no que se refere ao pedido definitivo no sentido de "determinar ao Governo Federal que elabore e encaminhe ao STF, no prazo máximo de 3 meses, um plano nacional (“ Plano Nacional") visando à superação do Estado de Coisas Inconstitucional do sistema penitenciário brasileiro, dentro de um prazo de 3 anos", conforme petição inicial, o Ministro Luís Roberto Barroso, considerando a importância de tal pedido, sugeriu medida cautelar de ofício, qual seja: a determinação ao Governo Federal para que encaminhe ao Supremo Tribunal Federal um diagnóstico, a partir da coleta de dados, em termos quantitativos e pecuniários.

Neste sentido, por maioria, o Tribunal deferiu a concessão de cautelar de ofício, que fora proposta pelo Ministro Luís Roberto Barroso, determinando-se à União e aos Estados, e de modo específico ao Estado de São Paulo, para que encaminhem ao STF informes com relação à situação prisional brasileira.

\section{CONSIDERAÇÕES FINAIS}

À luz do princípio da dignidade da pessoa humana e da humanização da pena, conclui-se, portanto, que a ausência de condições mínimas e a violação generalizada e sistêmica dos direitos fundamentais ao longo do cumprimento da pena privativa de liberdade resultam na caracterização do Estado de Coisas Inconstitucional, exigindo-se do STF uma postura no sentido do ativismo judicial. Isto porque, o Estado, na posição de garante, deve cuidar da integridade dos presos e da incolumidade de todos os direitos e garantias não alcançados pela sentença penal condenatória; e, não o fazendo, legitima a Corte Constitucional a atuar em matéria de políticas públicas, que, a priori, não é de sua competência. O ativismo judicial é o que se espera do Supremo Tribunal Federal a partir da ADPF 347. 
A Constituição Federal brasileira, orientada pela dignidade da pessoa humana - axioma inerente a todo e qualquer ser humano, independentemente de qualquer condição -, estabelece um conjunto de direitos e garantias fundamentais, abrangendo, ainda, outros direitos dispostos em Tratados Internacionais ou Legislação Infraconstitucional que, devido o seu conteúdo e harmonização com os preceitos constitucionais, a eles podem ser equiparados.

A dignidade da pessoa humana exige por parte do Estado e da comunidade a abstenção de qualquer conduta de tendência degradante ou desumana, bem como a garantia das condições mínimas existenciais para uma vida satisfatória. No âmbito da execução da pena privativa de liberdade, há que se reverenciar o imperativo contido na Lei de Execução Penal: a humanização da pena em consonância com concretização da sentença penal condenatória transitada em julgado, ou, de acordo com o novo entendimento do STF, da decisão de segundo grau. Isto significa dizer que ao preso não pode ser imposta condição mais gravosa que a própria pena, garantindo-lhe a incolumidade dos demais direitos fundamentais não atingidos por ela.

Apesar do garantismo deste Estado Democrático de Direito, o quadro fático do sistema carcerário brasileiro revela desmedida contraposição inconstitucional, que é a violação generalizada e sistêmica aos direitos fundamentais, decorrente de condutas comissivas e omissivas do Poder Público, além da constante incapacidade estatal em modificar tal conjuntura. Em face da supressão de preceitos constitucionais, Luís Roberto Barroso denomina o contexto de "frustração constitucional", referindo-se às normas constitucionais que "invocam o que não está presente, afirmam o que não é verdade e prometem o que não será cumprido $^{15,}$.

O sistema carcerário brasileiro revela a existência de um cenário caótico de lesão a preceitos fundamentais, resultado da contínua inércia ou incapacidade das instituições legislativas e, principalmente, das administrativas. São exemplos das situações enfrentadas no cárcere: celas superlotadas, inúmeros problemas de higiene e risco de transmissão de doenças, falta de acesso à educação e alimentação adequada, a crescente violência interna, além da tortura cometida pelos agentes do Estado nos espaços de confinamento.

${ }^{15}$ BARROSO, Luís Roberto. O direito constitucional e a efetividade de suas normas: limites e possibilidades da Constituição brasileira. 3. ed. Rio de Janeiro: Renovar, 1996, p. 84. 
Neste diapasão, pela primeira vez no Brasil, o Supremo Tribunal Federal declarou, em julgamento da medida cautelar da ADPF 347, que o próprio sistema carcerário brasileiro configura um Estado de Coisas Inconstitucional, sendo que, para a superação, é necessária a atuação conjunta dos vários órgãos públicos, no âmbito da União, do Distrito Federal e dos Estados federados.

\section{REFERÊNCIAS BIBLIOGRÁFICAS}

BARROSO, Luís Roberto. O direito constitucional e a efetividade de suas normas: limites e possibilidades da Constituição brasileira. 3. ed. Rio de Janeiro: Renovar, 1996.

Senado, 1988.

Constituição (1988). Constituição da República Federativa do Brasil. Brasília, DF,

Lei n. ${ }^{\circ} 7.210$ de 11 de julho de 1984. Institui a Lei de Execução Penal. Disponível em:

<http://www.planalto.gov.br/ccivil_03/LEIS/L7210.htm〉. Acesso em: 18 fev. 2018.

Supremo Tribunal Federal. Ação de Arguição de Descumprimento de Preceito Fundamental n. ${ }^{\circ} 347$. Rio de Janeiro, 26 de maio de 2015.

CAMPOS, Carlos Alexandre de Azevedo. Estado de coisas inconstitucional. Salvador: JusPodivm, 2016.

CONVENÇÃO AMERICANA SOBRE DIREITOS HUMANOS, 1969. Disponível em: <http://www.planalto.gov.br/ccivil_03/Decreto/D0678.htm〉. Acesso em: 17 jan. 2018.

CONVENÇÃO CONTRA A TORTURA E OUTROS TRATAMENTOS OU PENAS CRUÉIS, DESUMANOS E DEGRADANTES. Adotada em Assembleia-Geral das Nações Unidas. Nova York, 1984. Disponível em: 〈http://www.planalto.gov.br/ccivil_03/decreto/1990-1994/D0040.htm>. Acesso em: 10 jan. 2018.

HERNÁNDEZ, Clara Inés Vargas. La Garatía de la dimensión objetiva de los derechos fundamentales y labor del juez constitucional colombiano em sede de acción de tutela: el llamado "estado de cosas inconstitucional". Revista del Centro de Estudios Constitucionales Ano 1, no 1 , Universidad de Talca, Chile, 2003.

INFOPEN - Ministério Da Justiça - Levantamento nacional de informações penitenciárias - dados consolidados Junho/2016. Disponível em: <http://depen.gov.br/DEPEN/noticias-1/noticias/infopenlevantamento-nacional-de-informacoes-penitenciarias-2016/relatorio_2016_22111.pdf >. Acesso em: 08 jul. 2018.

MARMELSTEIN, George. Curso de direitos fundamentais. 6. ed. São Paulo: Atlas, 2016.

Mirabete, Julio Fabrini. Execução Penal: Comentários à Lei 7.210, de 11-7-1984. 11. ed. Editora Atlas, São Paulo: 2004. 
MIRANDA, Jorge. Manual de direito constitucional, tomo IV. 3. Ed. Coimbra: Coimbra, 2000.

PACTO INTERNACIONAL SOBRE DIREITOS CIVIS E POLÍTICOS. Adotado em AssembleiaGeral das Nações Unidas, 1966. Ratificado pelo Brasil em 24 de janeiro de 1992. Disponível em: <http://www.direitoshumanos.usp.br/index.php/Sistema-Global.-Declara\%C3\%A7\%C3\%B5es-eTratados-Internacionais-de-Prote $\% \mathrm{C} 3 \% \mathrm{~A} 7 \% \mathrm{C} 3 \% \mathrm{~A} 3 \mathrm{o} /$ pacto-internacional-dos-direitos-economicossociais-e-culturais-1966.html>. Acesso em: 13 mar. 2018.

SARLET, Ingo Wolfgang. A eficácia dos direitos fundamentais. 2. ed. Porto Alegre: Livraria do Advogado, 2001.

VARGAS, Alexis Galiás de Souza; BASTOS, Celso Ribeiro. Argüição de descumprimento de preceito fundamental. São Paulo: Revista dos Tribunais, 2000. 